\title{
KONTRIBUSI DISIPLIN BELAJAR DAN MOTIVASI BERPRESTASI TERHADAP HASIL BELAJAR MATEMATIKA
}

\author{
Komang Mia Sutrisna Dewi ${ }^{1}$, Ign. Wayan Suwatra ${ }^{2}$, Made Suarjana ${ }^{3}$ \\ 1,2,3 Jurusan Pendidikan Guru Sekolah Dasar, FIP Universitas Pendidikan Ganesha \\ Singaraja, Indonesia \\ e-mail: miasutrisnadewi@yahoo.com ${ }^{1}$, wayansuwatra@yahoo.co.id ${ }^{2}$, \\ suarjana undiksha@yahoo.co.id ${ }^{3}$
}

\begin{abstract}
ABSTRAK
Penelitian ini bertujuan untuk mengetahui kontribusi disiplin belajar dan motivasi berprestasi terhadap hasil belajar matematika siswa kelas V SD di Gugus III Kecamatan Sawan Tahun Pelajaran 2017/2018. Penelitian ini adalah penelitian "ex-post facto" dengan jumlah populasi 163 orang dan jumlah sampel 110 orang. Penentuan sampel pada penelitian ini menggunakan teknik random sampling. Alat pengumpul data berupa kuesioner dan pencatatan dokumen, analisis data dengan teknik regresi sederhana dan regresi ganda. Hasil penelitian menunjukkan bahwa: 1) terdapat hubungan yang signifikan antara disiplin belajar terhadap hasil belajar matematika dengan koefisien korelasi sebesar 0,475 , kontribusi sebesar $22,5 \%$, dan sumbangan efektifnya sebesar $17,29 \%$, 2) terdapat hubungan yang signifikan antara motivasi berprestasi terhadap hasil belajar matematika dengan koefisisen korelasi sebesar 0,573 , kontribusi sebesar $32,8 \%$, dan sumbangan efektifnya sebesar $28,21 \%$, 3) secara bersama-sama terdapat hubungan yang signifikan antara disiplin belajar dan motivasi berprestasi terhadap hasil belajar matematika dengan koefesien korelasi sebesar 0,675 dan kontribusinya sebesar 45,5\% terhadap hasil belajar matematika siswa kelas V SD di gugus III Kecamatan Sawan Tahun Pelajaran 2017/2018.
\end{abstract}

Kata-kata kunci : disiplin belajar, hasil belajar, motivasi berprestasi

\begin{abstract}
This study aims was to determine the contribution of study discipline and achievement motivation towards learning outcomes student of class V SD di Gugus III Sawan Subdistric, academic year 2017/2018. This research is "ex-post facto" with the amount of population is 163 people and a sample of 123 people. Determination of the sample in this study using random sampling techniques. Data collection tool is a questionnaire and recording of documents, analysis of data using by simple regression and multiple regrresions. The results showed that: 1) there is a significant correlations between study discpline on learning outcomes mathematics with a correlation coefficient of 0,475 , a contribution amounting to $22,5 \%$, and effective contribution amounting to $17,29,2)$ there is a significant correlation between achievement motivation on learning outcomes mathematic with a correlation coefficient of, 0,573, a contribution amounting to $32,8 \%$, and effective contribution amounting to $28,21 \%, 3$ ) with the same, there is a significant correlation between study discipline and achievement motivation towards learning outcomes mathematic with a correlation coefficient of 0,675 and a contribution amounting to $45,5 \%$ to the learning outcomes student of class V SD di Gugus III Sawan Subdistric, academic year 2017/2018.
\end{abstract}

Keywords: study discipline, achievement motivation, learning outcomes 


\section{Pendahuluan}

Pendidikan merupakan sarana utama untuk meningkatkan sumber daya manusia. Pendidikan menunjang kualitas dari sumber daya manusia yang dapat bersaing pada era globalisasi ini. Kosasih (2013) berpendapat, pendidikan pada hakekatnya adalah usaha untuk mencerdaskan kehidupan manusia atau proses memanusiakan manusia yang diselenggarakan melalui proses pendidikan. Pendidikan akan membawa manusia lebih berkembang dalam kehidupannya dan mampu memenuhi setiap kebutuhan. Pendidikan adalah salah satu perwujudan kebudayaan manusia yang dinamis dan sarat perkembangan (Saputra:2017). Pendidikan akan membawa manusia lebih berkembang dalam kehidupannya dan mampu memenuhi setiap kebutuhan. Menurut Undang-Undang (UU) terbaru yang mengatur tentang pengertian pendidikan adalah UU Nomor 20 tahun 2003 tentang Sistem Pendidikan Nasional dinyatakan pendidikan adalah usaha sadar terencana untuk mewujudkan suasana belajar dan proses pembelajaran agar peserta didik secara aktif mengembangkan potensi dirinya untuk memiliki kekuatan spiritual, keagamaan, pengendalian diri, kepribadian kecerdasan, akhlak mulia serta keterampilan yang diperlukan dirinya, masyarakat dan bangsanya. Berdasarkan pandangan beberapa ahli tersebut, dapat disimpulkan bahwa pendidikan merupakan usaha sadar terencana untuk memanusiakan manusia, yang diwujudkan melalui suasana belajar dan proses pembelajaran agar peserta didik dapat mengembangkan potensi diri, meliputi budi pekerti, pikiran dan jasmani yang diperlukan dirinya, masyarakat dan bangsanya.

Dalam UU ini juga dijelaskan bahwa tujuan pendidikan nasional yaitu untuk mengembangkan kemampuan dan membentuk watak serta peradaban bangsa yang bermartabat dalam rangka mencerdaskan kehidupan bangsa, bertujuan mengembangkan potensi peserta didik agar menjadi manusia yang beriman dan bertaqwa kepada Tuhan Yang Maha Esa, berakhlak mulia, sehat, berilmu, cakap, kreatif, mandiri, dan menjadi warga Negara yang demokratis serta bertanggung jawab.

Agar dapat mencapai tujuan pendidikan memang tidaklah mudah. Tujuan pendidikan dapat tercapai apabila didukung oleh seluruh pihak yang berkaitan dengan pendidikan tersebut. Sebuah pendidikan tidak dapat terlepas dari adanya proses pembelajaran. Tujuan pembelajaran akan tercapai apabila setiap proses dari pembelajaran tersebut dapat dilaksanakan dengan baik. Terjadinya proses pembelajaran yang baik ditentukan oleh beberapa faktor yaitu faktor internal dari subjek didik, faktor eksternal berupa lingkungan fisik, faktor sistem yang berlaku dalam suatu institusi pendidikan, dan faktor tujuan yang ingin dicapai (Kosasih, 2013).

Berbagai upaya telah dilakukan oleh pemerintah untuk mewujudkan pendidikan berkualitas tinggi dengan tujuan menciptakan sumber daya manusia yang berkualitas. Sekolah Dasar (SD) merupakan salah satu jenjang pendidikan yang ditempuh untuk menjalankan proses pembelajaran. Matematika sangat penting untuk diterapkan dalam kehidupan seharihari maupun dalam menghadapi kemajuan IPTEK sehingga matematika perlu diberikan kepada setiap peserta didik sejak menginjak jenjang SD, bahkan sejak Taman Kanak-kanak.

Perlu disadari bahwa dibelajarkannya matematika kepada semua peserta didik mulai dari tingkat sekolah dasar adalah untuk membekali mereka berbagai kemampuan seperti: kemampuan berpikir logis, analitis, sistematis, kritis dan kreatif, serta kemampuan bekerjasama. Selama ini siswa masih menganggap bahwa matematika merupakan pelajaran yang membosankan dan sulit. Adanya pandangan seperti itu akan membuat siswa malas untuk belajar matematika dan motivasi siswa untuk berprestasi dalam matematika juga semakin berkurang. Hal ini tentu akan mempengaruhi hasil belajar matematika peserta didik. Hasil belajar matematika merupakan perubahan tingkah laku pada ranah kognitif, afektif,dan psikomotor berkaitan dengan logika dan kemampuan berpikir dalam penyelesaiasalah seharihari yang didapatkan setelah memeroleh pengalaman atau interaksi belajar matematika. Hasil belajar matematika dapat dikatakan sebagai kesimpulan umum yang dapat menjadi acuan sejauh mana keberhasilan proses pembelajaran matematika. 
Adanya upaya-upaya pemerintah dan pendidik untuk menyediakan pelayanan belajar yang baik diharapkan dapat meningkatkan hasil belajar siswa menjadi optimal dan sumber daya manusia yang berkualitas dapat tercapai. Pada kenyataannya tujuan tersebut belum terealisasikan sepenuhnya. Ini terlihat dari studi dokumentasi hasil belajar siswa yang masih rendah, khususnya pada mata pelajaran Matematika siswa kelas V SD di Gugus III Kecamatan Sawan Tahun Pelajaran 2017/2018. Diketahui bahwa jumlah siswa yang mencapai KKM sebanyak 40 siswa dan yang belum mencapai KKM sebanyak 123 siswa dari total 163 siswa. Jika dilihat dari rata-rata persentase pencapaian KKM, sebanyak $74,02 \%$ belum mencapai KKM dan hanya 25,98\% yang mencapai KKM. Jadi, dari data tersebut dapat disimpulkan bahwa hasil belajar matematika siswa masih rendah.

Berdasarkan hasil wawancara dan observasi, tampak bahwa dalam proses pembelajaran matematika siswa kelas V SD di Gugus III Kecamatan Sawan telah ditingkatkan berbagai upaya pada bidang media, sumber, metode, dan strategi pembelajaran dengan baik. Akan tetapi teknik dan keteraturan siswa dalam aktivitas pembelajaran di rumah dan sekolah masih kurang teratur dan tidak diperhatikan.

Hasil belajar peserta didik dipengaruhi oleh dua faktor utama, yakni faktor dari dalam diri siswa (internal factor) dan faktor yang datang dari luar diri siswa atau faktor lingkungan (external factor). Faktor dari dalam diri siswa terutama menyangkut kemampuan yang dimiliki siswa. Faktor eksternal dan internal ini akan menunjang kegiatan pembelajaran dan dapat juga menghambat kegiatan pembelajaran.

Salah satu faktor internal individu yang berpengaruh terhadap hasil belajar matematika adalah disiplin belajar. Sikap disiplin yang dimiliki anak harus ditanamkan dalam interaksi belajar. Hal tersebut sejalan dengan pendapat James (2004) mengatakan bahwa anak-anak juga perlu diajari tentang mendisiplinkan dirinya sendiri, serta perilaku yang bertanggungjawab. Menurut Sofyan (2013) kedisiplinan menyangkut giatnya usaha dan memenuhi target serta waktu yang tepat. Menurut Sardiman (2011), disiplin dalam interaksi belajar-mengajar ini diartikan sebagai suatu pola tingkah laku yang diatur sedemikian rupa menurut ketentuan yang sudah ditaati oleh semua pihak dengan secara sadar, baik pihak guru maupun pihak siswa.

Dapat disimpulkan bahwa disiplin belajar merupakan teknik atau cara belajar yang dilakukan sesuai dengan aturan yang berlaku. Adanya sikap disiplin belajar memungkinkan siswa mencapai hasil belajar optimal yang berpengaruh pada pembentukan watak atau kepribadian yang baik pula. Disiplin belajar perlu ditanamkan pada diri individu dalam kegiatan pembelajaran matematika. Disiplin belajar akan menjadi faktor tercapainya hasil belajar matematika yang optimal.

Selain disiplin belajar, motivasi berprestasi juga memiliki pengaruh terhadap hasil belajar siswa. "Motivasi merupakan kondisi psikologis yang mendorong seseorang untuk melakukan sesuatu atau kekuatan yang terdapat dalam diri organisme yang mendorong untuk berbuat" (Kosasih, 2013:19). Menurut Djamarah (1994) seluruh aktivitas belajar siswa adalah untuk mendapatkan prestasi belajar yang baik. Setiap siswa yang memiliki motivasi berprestasi pasti ingin memperoleh prestasi belajar yang baik dan optimal. Menurut Sofyan (2013) motivasi berprestasi merupakan suatu dorongan dari dalam diri untuk selalu meraih prestasi. Apabila dorongan itu tinggi, maka keberhasilan akan semakin besar untuk tercapai. Mardiastuti (2016:2) mengungkapkan bahwa motivasi berprestasi mempengaruhi hasil belajar, tinggi rendahnya motivasi selalu dijadikan indikator baik buruknya hasil belajar peserta didik.

Dapat disimpulkan bahwa motivasi berprestasi merupakan dorongan yang dimiliki oleh seseorang untuk selalu meraih prestasi. Motivasi berprestasi dalam diri siswa sangat penting untuk diperhatikan oleh berbagai pihak, termasuk orang tua siswa. Adanya Motivasi berprestasi tinggi akan meningkatkan hasil belajar matematika siswa.

Disiplin belajar dan motivasi berprestasi yang terdapat dalam kelas biasanya berbedabeda tergantung pada individu siswa itu sendiri. Jika guru dapat menumbuhkan sikap disiplin belajar siswa serta memotivasi siswa untuk berprestasi dalam kegiatan pembelajaran khususnya matematika, maka akan terjadi perubahan hasil belajar siswa.

Akan tetapi, sejauh mana disiplin belajar dan motivasi berprestasi berkontribusi terhadap hasil belajar matematika belum dapat diketahui. Paparan tersebut mengindikasikan perlunya 
mengetahui kontribusi faktor disiplin belajar dan motivasi berprestasi terhadap hasil belajar pada mata pelajaran matematika sehingga dapat dijadikan bahan pertimbangan yang penting untuk menentukan keberhasilan pembelajaran di kelas dan mencapai tujuan pendidikan. Oleh sebab itu, permasalahan ini perlu diangkat melalui penelitian yang berjudul "Kontribusi Disiplin Belajar dan Motivasi Berprestasi Terhadap Hasil Belajar Matematika Siswa Kelas V SD di Gugus III Kecamatan Sawan Tahun Pelajaran 2017/2018".

Berdasarkan rumusan masalah tersebut, maka tujuan penelitian ini adalah 1) untuk mengetahui hubungan antara disiplin belajar terhadap hasil belajar matematika siswa kelas $\mathrm{V}$ SD di Gugus III Kecamatan Sawan Tahun Pelajaran 2017/2018, 2) untuk mengetahui hubungan antara motivasi berprestasi terhadap hasil belajar matematika siswa kelas V SD di Gugus III Kecamatan Sawan Tahun Pelajaran 2017/2018, 3) untuk mengetahui hubungan antara disiplin belajar dan motivasi berprestasi secara bersama-sama terhadap hasil belajar matematika siswa kelas V SD di Gugus III Kecamatan Sawan Tahun Pelajaran 2017/2018. 4) untuk mengetahui seberapa besar kontribusi disiplin belajar dan motivasi berprestasi secara sendiri maupun bersama-sama terhadap hasil belajar matematika siswa kelas V SD di Gugus III Kecamatan Sawan Tahun Pelajaran 2017/2018.

Hasil penelitian ini diharapkan dapat memberikan manfaat sebagai berikut. Secara teoritis, hasil penelitian ini dapat memberikan manfaat bagi pengembangan pembelajaran Indonesia yang memberikan informasi mengenai pentingnya sikap disiplin belajar dan motivasi berprestasi siswa terhadap pembelajaran. Secara praktis yaitu:1) bagi siswa, hasil penelitian ini diharapkan memberikan pemahaman kepada siswa mengenai pentingnya memiliki disiplin belajar dan motivasi berprestasi dalam belajar, 2) bagi guru, hasil penelitian ini diharapkan dapat menjadi bahan pertimbangan guru dalam merancang kegiatan pembelajaran sehingga dapat menumbuhkan disiplin belajar siswa dan motivasi berprestasi siswa, 3) bagi sekolah, hasil penelitian ini diharapkan dapat berguna untuk meningkatkan wawasan seluruh warga sekolah yang berkaitan dengan disiplin belajar dan motivasi berprestasi, 4) hasil penelitian ini diharapkan dapat menjadi literatur bagi para peneliti bidang pendidikan terkait dengan disiplin belajar dan motivasi berprestasi siswa.

\section{Metode}

Penelitian ini adalah penelitian "ex-post facto" yang artinya kejadian atau fakta ini sudah terjadi. Penelitian ini bersifat pengungkapan fakta yang ada melalui analisis hubungan antar variabel, sehingga hubungan antar variabel tersebut menjadi jelas. Variabel bebas dalam penelitian ini terdiri dari disiplin belajar $\left(X_{1}\right)$ dan motivasi berprestasi $\left(X_{2}\right)$, sedangkan variabel terikat adalah hasil belajar matematika siswa kelas V SD di Gugus III Kecamatan Sawan Tahun Pelajaran 2017/2018.

Populasi dalam penelitian ini adalah seluruh siswa kelas V SD di Gugus III Kecamatan Sawan Tahun Pelajaran 2017/2018 yang tersebar ke dalam 7 SD dan berjumlah 163 orang. Sedangkan jumlah sampel 110 orang. Penentuan sampel pada penelitian ini menggunakan teknik random sampling.

Data yang terkumpul dalam penelitian ini adalah data tentang disiplin belajar dan motivasi berprestasi terhadap hasil belajar matematika siswa kelas V SD di Gugus III Kecamatan Sawan. Untuk memperoleh data tersebut digunakan instrumen berupa kuesioner disiplin belajar dan kuesioner motivasi berprestasi. Untuk data hasil belajar didapatkan melalui pencatatan dokumen. Kuesioner merupakan teknik pengumpulan data yang dilakukan dengan cara memberi seperangkat pertanyaan atau pernyataan tertulis kepada responden untuk dijawab.

Sebelum digunakan dalam penelitian, perlu dilakukan uji coba terhadap instrumen kuesioner disiplin belajar dan motivasi berprestasi. Tujuan dilakukan uji coba adalah untuk mengetahui tingkat validitas dan reliabilitas instrumen penelitian. Validitas yang dihitung adalah validitas isi dengan analisis gregory dan validitas butir dianalisis dengan analisis product moment, serta reliabilitas dianalisis dengan alpha cornbach. 
Pada penelitian ini, digunakan dua motode analisis yaitu metode analisis statistik deskriptif dan statistik inferensial. Metode analisis statistik deskriptif mencari mean, median, mode, standar deviasi, distribusi skor dan histogram digunakan dengan cara manual. Untuk menentukan tingkat klarifikasi kecenderungan dari masing-masing variabel yang diteliti digunakan pedoman konversi skala lima. Data yang diperoleh berskala interval. Uji prasyarat yang perlu diuji untuk dapat dianalisis lebih lanjut adalah uji normalitas, linearitas, multikolinieritas, autokorelasi, dan heterokedastisitas.

Data yang akan dianalisis korelasi dan regresi harus memenuhi uji prasyarat. Uji hipotesis korelasi dan kontribusi masing-masing variabel bebas terhadap variabel terikat dilakukan dengan menggunakan rumus regresi sederhana untuk hipotesis I dan II, sedangkan menggunakan rumus regresi ganda untuk hhipotesis III. Pengujian hopotesis dilakukan dengan menggunakan taraf signifikansi $5 \%$. Jika nilai $F_{\text {reg }}>$ dari $F_{\text {tabel }}$ berarti hipotesis diterima, dan sebaliknya jika $F_{\text {reg }}<F_{\text {tabel }}$ hoptesis ditolak. Pengujian hipotesis dilakukan dengan bantuan SPSS 17.0 for Windows.

\section{Hasil dan Pembahasan}

Data hasil penelitian yang dianalisis adalah data berbentuk skor. Data disiplin belajar dan motivasi berprestasi didapatkan dari pemberian kuesioner, sedangkan data hasil belajar matematika didapatkan dari pencatatan dokumen. Instrumen yang digunakan untuk data disiplin belajar dan motivasi berprestasi yang digunakan sudah valid secara kriteria yang ditetapkan berdasarkan hasil analisis uji coba instrumen penelitian. Jumlah soal kuesioner masing-masing variabel yaitu 30 butir. Rincian data tentang kedua pembelajaran tersebut dianalisis dengan statistik deskriptif yang dihitung secara manual. Deskripsi data disiplin belajar, motivasi berprestasi, dan hasil belajar matematika disajikan pada Tabel 1.

Tabel 1. Rekapitulasi Hasil Perhitungan Disiplin Belajar, Motivasi Berprestasi, dan Hasil Belajar Matematika

\begin{tabular}{cccc}
\hline Statistik & & Variabel & \\
Deskriptif & Disiplin Belajar & Motivasi Berprestasi & Hasil Belajar Matematika \\
\hline Mean & 112,24 & 119,17 & 69,25 \\
Median & 115,35 & 118,41 & 71,31 \\
Modus & 111,65 & 120,64 & 68,92 \\
Varians & 119,74 & 85,15 & 74,67 \\
Standar Deviasi & 10,94 & 9,23 & 8,64 \\
Skor Maksimum & 139 & 139 & 85 \\
Skor Minimum & 89 & 95 & 51 \\
Rentangan & 51 & 45 & 35 \\
\hline
\end{tabular}

Hasil perhitungan analisis deskriptif menunjukkan bahwa rata-rata skor disiplin belajar siswa adalah 112,24, rata-rata skor motivasi berprestasi 119,17, dan rata-rata skor hasil belajar matematika adalah 69,25. Untuk menentukan tinggi rendahnya kualitas variabel maka skor rata-rata (mean) tiap-tiap variabel dikonversikan dengan menggunakan kriteria rata-rata ideal $\left(\mathrm{M}_{\mathrm{i}}\right)$ dan standar deviasi ideal $\left(\mathrm{SD}_{\mathrm{i}}\right)$. Nilai rata-rata skor disiplin belajar adalah 112,24 , rata-rata skor disiplin belajar terletak pada kategori tinggi. Nilai rata-rata motivasi berprestasi adalah 119,17 rata-rata skor motivasi berprestasi terletak pada kategori tinggi. Nilai rata-rata skor hasil belajar matematika adalah 69,25 , rata-rata skor hasil belajar matematika terletak pada kategori tinggi.

Hasil uji prasyarat menunjukkan data berdistribusi normal. Data disiplin belajar dengan hasil belajar matematika memiliki hubungan yang linear, dan data motivasi berprestasi dengan hasil belajar matematika memiliki hubungan yang linear. Data hasil penelitian juga menunjukkan tidak terjadi masalah multikolinearitas, autokorelasi, dan heterokedastisitas. 
Merujuk pada hasil uji prasyarat tersebut, uji hipotesis I dan II dapat dilakukan dengan analisis regresi sederhana, dan uji hipotesis III dapat dilakukan dengan analisis regresi ganda. Adapun hasil analisis regresi sederhana dan regresi ganda disajikan pada Tabel 2.

Tabel 2. Ringkasan Hasil Analisis Data Hubungan antar Variabel

\begin{tabular}{ccccc}
\hline $\begin{array}{c}\text { Hubungan antar } \\
\text { Variabel }\end{array}$ & Persamaan Garis Regresi & $\begin{array}{c}\text { Koefisien } \\
\text { Korelasi }\end{array}$ & $\begin{array}{c}\text { Kontribusi } \\
(\%)\end{array}$ & $\begin{array}{c}\text { Sumbangan } \\
\text { Efektif (SE) } \\
\%\end{array}$ \\
\hline $\mathrm{X}_{1}$ terhadap Y & $\hat{\mathrm{y}}=27,176+0,375 X 1$ & 0,475 & 22,5 & 17,29 \\
$\mathrm{X}_{2}$ terhadap $\mathrm{Y}$ & $\hat{\mathrm{y}}=5,325+0,536 \mathrm{X} 2$ & 0,573 & 32,8 & 28,21 \\
$\mathrm{X}_{1}$ dan $\mathrm{X}_{2}$ & $\hat{\mathrm{y}}=18,035+0,289 \mathrm{X} 1+0,460 \mathrm{X} 2$ & 0,675 & 45,5 & 45,5 \\
terhadap Y & Signifikan dan linier & Signifikan & - & - \\
Keterangan & & &
\end{tabular}

Hubungan Disiplin Belajar terhadap Hasil Belajar Matematika

Berdasarkan analisis yang telah dilakukan, secara normatif ditemukan bahwa disiplin belajar berada pada kategori tinggi. Selain itu, hasil analisis juga menunjukkan bahwa terdapat korelasi yang signifikan antara disiplin belajar dengan hasil belajar matematika siswa kelas $\mathrm{V}$ SD di Gugus III Kecamatan Sawan melalui persamaan garis regresi ŷ $=27,176+0,375$ X1 dengan $F_{\text {reg }}=31,424(p<0,05)$. Korelasi antara disiplin belajar dengan hasil belajar matematika adalah signifikan yaitu sebesar 0,475 dengan $p<0,05$. Ini berarti semakin baik disiplin belajar, semakin baik pula hasil belajar matematika tersebut. Temuan ini mengindikasikan bahwa disiplin belajar siswa mempunyai peranan penting dalam meningkatkan hasil belajar matematika siswa kelas V SD di Gugus III Kecamatan Sawan. Sumbangan efektif (SE) variabel disiplin belajar terhadap hasil belajar matematika sebesar 18,50\%.

Hasil penelitian ini sesuai dengan konsep tentang disiplin belajar yang dikemukakan oleh Sudarma (2007) yang mengatakan disiplin belajar adalah titik pusat dalam pendidikan, tanpa disiplin tidak akan ada kesepakatan antara guru dan murid yang mengakibatkan pencapaian prestasi kurang optimal terutama dalam belajar.

Hasil penelitian ini juga sejalan dengan hasil penelitian yang dilaksanakan oleh Maja (2013) yang berjudul "Pengaruh Motivasi, Metode Pembelajaran dan Disiplin Belajar Terhadap Prestasi Belajar Matematika Teknik di Politeknik Negeri Sriwijaya". Hasil penelitian menemukan bahwa terdapat: (1) kontribusi motivasi $\left(X_{1}\right)$ terhadap prestasi belajar matematika sebesar $47,3 \%$, (2) kontribusi metode pembelajaran $\left(X_{2}\right)$ terhadap prestasi belajar matematika sebesar $13 \%$, (3) kontribusi disiplin belajar $\left(X_{3}\right)$ terhadap prestasi belajar matematika sebesar $32,9 \%$, (4) kontribusi bersama-sama antara motivasi, metode pembelajaran, dan disiplin belajar terhadap prestasi belajar matematika sebesar $71,2 \%$. Dengan hasil tersebut dapat disimpulkan bahwa terdapat hubungan yang positif dan signifikan motivasi, metode pembelajaran, dan disiplin belajar terhadap prestasi belajar matematika teknik di Politeknik Negeri Sriwijaya.

Hasil belajar siswa dipengaruhi oleh banyak faktor. Faktor tersebut meliputi faktor internal (siswa), salah satunya mengenai disiplin belajar siswa dan faktor eksternal yaitu pendekatan pembelajaran. Kesesuaian antara disiplin belajar siswa dengan pendekatan pembelajaran yang diterapkan guru sangat berpengaruh terhadap hasil belajarnya.

Siswa yang memiliki disiplin belajar tinggi cenderung aktif dan disiplin dalam kegiatan pembelajaran. Menurut Yamin (2009) dengan adanya disiplin belajar, para peserta didik bersedia untuk tunduk dan mengikuti peraturan tertentu serta menjauhi larangan. Kesediaan semacam ini dapat memelihara kepentingan bersama dan kelancaran tugas-tugas sekolah. Adanya disiplin belajar para peserta didik belajar hidup dengan pembiasaan yang baik, positif, dan bermanfaat bagi diri dan lingkungannya. Sikap disiplin belajar yang dimiliki siswa akan mendukung terciptanya kegiatan belajar mengajar yang efektif dan berguna mencapai hasil belajar yang optimal. 
Dengan demikian, semakin tinggi disiplin belajar siswa maka semakin tinggi hasil belajar matematika siswa. Sebaliknya, semakin rendah disiplin belajar siswa, maka semakin rendah pula hasil belajar matematika siswa. Hal ini berarti terdapat hubungan yang signifikan disiplin belajar terhadap hasil belajar matematika siswa.

Hubungan Motivasi Berprestasi Terhadap Hasil Belajar Matematika

Berdasarkan analisis yang telah dilakukan, secara normatif ditemukan bahwa motivasi berprestasi berada pada kategori tinggi. Selain itu, hasil analisis juga menunjukkan bahwa terdapat korelasi yang signifikan antara motivasi berprestasi terhadap hasil belajar matematika siswa kelas V SD di Gugus III Kecamatan Sawan dengan persamaan regresi ŷ $=5,325+0,536$ $\mathrm{X} 2$ dan $\mathrm{F}_{\text {reg }}=52,759(\mathrm{p}<0,05)$. Korelasi antara motivasi berprestasi terhadap hasil belajar matematika adalah signifikan yaitu sebesar 0,573 dengan $p<0,05$. Ini berarti semakin baik motivasi berprestasi, maka semakin baik hasil belajar matematika tersebut. Temuan ini mengindikasikan bahwa motivasi berprestasi mempunyai peranan penting dalam meningkatkan hasil belajar matematika siswa. Sumbangan efektif (SE) variabel motivasi berprestasi terhadap hasil belajar matematika sebesar $27 \%$.

Hasil penelitian ini sesuai dengan konsep motivasi berprestasi yang dikemukakan oleh Djaali (2008), yang mengatakan motivasi berprestasi merupakan kondisi fisiologis dan psikologis (kebutuhan untuk berprestasi) terdapat dalam diri siswa yang mendorongnya untuk melakukan aktivitas tertentu guna mencapai suatu tujuan tertentu (berprestasi setinggi mungkin). Aspriyani (2017) juga mengatakan motivasi berprestasi merupakan dorongan atau motif yang ada dalam setiap diri siswa guna mengarahkan tingkah lakunya agar tercapai suatu keberhasilan dalam belajar.

Hasil penelitan ini juga sejalan dengan hasil penelitian yang dilaksanakan oleh Toni (2013) yang berjudul "Determinasi Konsep Diri, Motivasi Berprestasi, dan Disiplin Belajar terhadap Hasil Belajar IPA SD Se-Kecamatan Buleleng. Hasil penelitian ini menemukan bahwa, 1) terdapat hubungan yang positif dan signifikan antara konsep diri dengan hasil belajar IPA dengan kontribusi sebesar $21 \%$ dan sumbangan efektif sebesar 30,156\%; 2) terdapat hubungan yang positif dan signifikan antara motivasi berprestasi terhadap hasil belajar IPA dengan kontribusi sebesar $19 \%$ dan sumbangan efektif sebesar 29,185\%; 3) terdapat hubungan yang positif dan signifikan antara disiplin belajar terhadap hasil belajar IPA dengan kontribusi sebesar $13 \%$ dan sumbangan efektif sebesar $23,188 \%$, 4) terdapat hubungan yang positif dan signifikan antara konsep diri, motivasi berprestasi, dan disiplin belajar secara bersama-sama terhadap hasil belajar IPA dengan kontribusi sebesar 24\%. Dengan hasil tersebut dapat disimpulkan bahwa konsep diri, motivasi berprestasi, dan disiplin belajar yang dimiliki oleh siswa memiliki hubungan positif dan signifikan terhadap hasil belajar IPA.

Motivasi dapat diartikan sebagai kemauan/pendorong atau penarik seseorang untuk mau melaksanakan tugas dengan sebaik-baiknya. Motivasi merupakan suatu bentuk reaksi terhadap kebutuhan manusia yang menimbulkan eksistensi dalam diri manusia yaitu keinginan terhadap sesuatu yang belum terpenuhi dalam hidupnya sehingga terdorong untuk melakukan tindakan guna memenuhi dan memuaskan keinginannya. Motivasi berprestasi tidak lain adalah motif atau dorongan dalam diri yang dapat mengarahkan tingkah laku siswa sehingga menyebabkan peningkatan aktivitas dalam kemampuan, guna berpacu dengan keunggulan orang lain dan diri sendiri untuk mendapatkan keberhasilan dalam mencapai tujuan termasuk hasil belajar.

Semakin tinggi motivasi berprestasi yang dimiliki siswa maka semakin tinggi pula hasil belajar matematika siswa. Sebaliknya, semakin rendah motivasi berprestasi siswa, maka semakin rendah pula hasil belajar matematika siswa Dengan demikian dapat disimpulkan bahwa terdapat hubungan yang signifikan motivasi berprestasi terhadap hasil belajar matematika siswa kelas V SD di Gugus III Kecamatan Sawan. 
Hubungan Bersama antara Disiplin Belajar dan Motivasi Berprestasi Terhadap Hasil Belajar Matematika

Berdasarkan analisis yang telah dilakukan, ditemukan bahwa secara bersama-sama terdapat korelasi yang signifikan antara disiplin belajar dan motivasi berprestasi terhadap hasil belajar matematika dengan garis regresi $\hat{y}=18,035+0,289 X 1+0,460 X 2$ dan $F_{\text {reg }}=44,723$ $(p<0,05)$. Korelasi antara disiplin belajar $(X 1)$ dan motivasi berprestasi $(X 2)$ terhadap hasil belajar matematika $(Y)$, diperoleh besar $r_{\text {hitung }}=0,849$. Ini berarti $r_{\text {hitung }}=0,849$ signifikan pada $\propto=0,05\left(r_{\text {tabel }}=0,195\right)$ dengan kontribusi $45,5 \%$. Sumbangan efektif yang diperoleh sebesar $45,5 \%$. Terdapatnya korelasi yang positif dan signifikan ini memiliki makna semakin tinggi skor disiplin belajar dan motivasi berprestasi yang dicapai oleh siswa maka semakin tinggi pula hasil belajar matematika yang dimiliki oleh siswa tersebut. Begitu juga sebaliknya, semakin rendah skor disiplin belajar dan motivasi berprestasi yang dicapai siswa maka semakin rendah pula hasil belajar matematika yang dimiliki oleh siswa tersebut.

Disiplin belajar dan motivasi berprestasi yang dimiliki oleh setiap siswa ternyata memiliki hubungan dengan hasil belajar siswa. Dengan disiplin belajar dan motivasi berprestasi yang tinggi akan meningkatkan hasil belajar yang dicapai oleh siswa. Disiplin belajar tinggi yang dimiliki siswa akan sangat mempengaruhi hasil dari kegiatan belajar siswa ke arah yang positif. Begitu pula dengan motivasi berprestasi tinggi yang dimiliki siswa dalam mengikuti proses pembelajaran akan berdampak positif dalam pencapaian hasil belajar siswa. Guru adalah fasilitator dalam kegiatan pembelajaran, guru juga bertugas menciptakan kedisiplinan dan sebagai motivator yang memotivasi siswanya. Dengan adanya kedisiplinan dalam belajar dan siswa memliki motivasi berprestasi, tentu akan berdampak positif terhadap hasil belajar siswa.

Jadi dapat disimpulkan bahwa terdapat hubungan yang signifikan disiplin belajar siswa dan motivasi berprestasi secara bersama-sama terhadap hasil belajar Matematika siswa kelas V SD di Gugus III Kecamatan Sawan.

Kontribusi Disiplin Belajar dan Motivasi Berprestasi terhadap Hasil Belajar Matematika

Berdasarkan analisis kontribusi variabel yang telah dilakukan, variabel disiplin belajar memberikan kontribusi sebesar 22,5\% terhadap hasil belajar matematika siswa kelas V SD di Gugus III Kecamatan Sawan. Variabel motivasi berprestasi memberikan kontribusi sebesar $32,8 \%$ terhadap hasil belajar matematika siswa kelas V SD di Gugus IIII Kecamatan Sawan. Secara bersama-sama variabel disiplin belajar dan motivasi berprestasi memberikan kontribusi sebesar $45,5 \%$ terhadap hasil belajar matematika siswa kelas V SD di Gugus III Kecamatan Sawan.

Adanya kontribusi antara disiplin belajar dan motivasi berprestasi secara sendiri maupun bersama-sama terhadap hasil belajar matematika menunjukkan bahwa terdapat kontribusi antara disiplin belajar dan motivasi berprestasi terhadap hasil belajar matematikas siswa kelas V SD di Gugus III Kecamatan Sawan Tahun Pelajaran 2017/2018.

Kontribusi disiplin belajar dan motivasi berprestasi secara bersama-sama yaitu $45,5 \%$. Hal tersebut berarti sebesar $54,5 \%$ hasil belajar matematika masih dipengaruhi oleh variabel lain dalam penelitian ini. Hasil belajar peserta didik dipengaruhi oleh dua faktor utama, yaitu faktor dari dalam diri siswa (internal factor) dan faktor yang datang dari luar diri siswa atau faktor lingkungan (external factor). Faktor dari dalam diri siswa misalnya motivasi belajar, minat belajar, gaya belajar dan lain-lain. Faktor dari luar diri siswa misalnya pola asuh orang tua, lingkungan belajar, dan lain sebagainya.

\section{Simpulan dan Saran}

Berdasarkan hasil penelitian dan analisis data statistik, maka dapat disimpulkan bahwa: 1) terdapat hubungan yang signifikan antara disiplin belajar terhadap hasil belajar matematika siswa kelas V SD di Gugus III Kecamatan Sawan Tahun Pelajaran 2017/2018. Dengan koefisien korelasi $r_{\text {hitung }}=0,475$ dan sumbangan efektif sebesar $18,50 \%$, 2) terdapat hubungan yang signifikan antara motivasi berprestsi terhadap hasil belajar matematika siswa kelas $V$ SD 
di Gugus III Kecamatan Sawan Tahun Pelajaran 2017/2018. Dengan koefisien korelasi $\mathrm{r}_{\text {hitung }}=$ 0,573 dan sumbangan efektif sebesar $27 \%$, 3) terdapat hubungan yang signifikan antara disiplin belajar dan motivasi berprestasi secara bersama-sama terhadap hasil belajar matematika siswa kelas V SD di Gugus III Kecamatan Sawan Tahun Pelajaran 2017/2018. Dengan koefiesien korelasi $\left.r_{\text {hitung }}=0,675,4\right)$ besar kontribusi disiplin belajar dan motivasi berprestasi secara sendiri maupun bersama-sama terhadap hasil belajar matematika siswa kelas V SD di Gugus III Kecamatan Sawan yaitu: (1) kontribusi disiplin belajar terhadap hasil belajar matematika siswa kelas V SD di Gugus III Kecamatan Sawan sebesar 22,5\%, (2) kontribusi motivasi berprestasi terhadap hasil belajar matematika siswa kelas V SD di Gugus III Kecamatan Sawan sebesar 32,8\%, (3) kontribusi disiplin belajar dan motivasi berprestasi secara bersama-sama terhadap hasil belajar matematika siswa kelas V SD di Gugus III Kecamatan Sawan sebesar 45,5\%.

Berdasarkan hasil penelitian dan kesimpulan yang telah dikemukakan, saran yang dapat disampaikan adalah sebagai berikut. 1) Siswa diharapkan senantiasa menanamkan dalam diri kemauan untuk belajar dan berprestasi di sekolah, di rumah dan di mana saja. Selain itu, kedisiplininan terhadap diri maupun aturan harus tetap terjaga. 2) Pihak sekolah terutama bagi guru mata pelajaran matematika, hasil penelitian ini dapat dijadikan bahan pertimbangan dalam merancang dan mengembangkan kegiatan belajar siswa agar selalu berusaha membantu siswa untuk membangun dan mengarahkan disiplin belajar yang positif terhadap pelajaran matematika, serta meningkatkan motivasi berprestasinya dalam melakukan kegiatan pembelajaran yang pada akhirnya dapat membantu siswa untuk meningkatkan hasil belajarnya 3) Hasil penelitian ini diharapkan dapat menjadi masukkan dan pembanding untuk mengembangkan penelitian pada variabel lain yang memengaruhi hasil belajar siswa.

\section{DAFTAR PUSTAKA}

Agung, A. A. Gede. 2014. Metodologi Penelitian Pendidikan. Singaraja: FIP Undiksha.

Anggara, I Gede. 2013. Penerapan Model Pembelajaran Problem-Based Learning Untuk Meningkatkan Aktivitas Dan Hasil Belajar Siswa Pada Mata

Aspriyani, Riski. 2017. "Pengaruh Motivasi Berprestasi Terhadap Kemampuan Pemecahan Masalah Matematis". JPPM, Volume 10, Nomor 1 (hlm. 17-23).

Djaali. 2008. Psikologi Pendidikan. Cetakan ke-3. Jakarta: Sinar Grafika Offset.

Djamarah, Syaiful Bahri. 1994. Prestasi Belajar dan Kompetensi Guru. Cetakan ke-1. Surabaya: Usana Offset Printing.doc. (diakses tanggal 06 Pebruari 2017).

Hamalik, Oemar. 2003. Belajar dan Pembelajaran. Jakarta: Rineka Cipta.

Heruman, 2012.Model Pembelajaran Matematika. Bandung: Remaja Rosda Karya.

Kosasih, Nandang dan Dede Sumarna. 2013. Pembelajaran Quantum dan Optimalisasi Kecerdasan. Bandung: Alfabeta.

Maja, Ibnu. 2013. "Pengaruh Motivasi, Metode Pembelajaran dan Disiplin Belajar Terhadap Prestasi Belajar Matematika Teknik di Politeknik Negeri Sriwijaya". Jurnal Orasi Bisnis, Edisi ke-9, ISSN 2085-1375 (hlm. 1-19).

Mardiastuti, Arifa. 2016. "Pengaruh Model Pembelajaran NHT dan Motivasi Berprestasi Terhadap Hasil Belajar IPA Kelas IV". E-journal PGSD Universitas Pendidikan Ganesha. Volume 4, Nomor 1 (hlm. 1-9). 
Nurkhotimah, Siti, Joharman, dan Suripto. 2017. Penerapan Model Problem Based Learning (Pbl) Dengan Media Konkret Untuk Meningkatkan Hasil Belajar Matematika Tentang Operasi Hitung Pecahan

Ni Made Winursiti (2017). Jurnal IImiah Sekolah Dasar. Vol. 1 (4) pp. 270-275 275 Pada Siswa Kelas V Sdn 1 Kuwayuhan Tahun Ajaran 2016/2017. E-Journal Universitas Sebelas Maret Surakarta, tersedia jurnal.fkip.uns.ac.id/index.php/pgsdkebumen/article/download/10158/7512

Nurkancana \& Sunartana. 1992. Evaluasi Hasil Belajar. Surabaya: Usaha Nasional.

Saputra, Henry Januar, dkk. 2017. "Keefektifan Pembelajaran IPA Menggunakan Model Complette Sentence Berbantuan Card Terhadap Hasil Belajar Siswa kelas III SDN Ngelowetan Kabupaten Demak". Jurnal IImiah Sekolah Dasar. Volume 1, Nomor 3 (hlm. 171-178).

Sardiman. 2011. Interaksi \& Motivasi Belajar Mengajar. Cetakan ke-20. Jakarta: PT RajaGrafindo Persada.

Sofyan, Willis. 2013. Psikologi Pendidikan. Cetakan ke-2. Bandung: Alfabeta.

Sriyanto. 2007. Strategi Sukses Menguasai Matematika. Yogyakarta: Indonesia Cerdas Strauss.

Sudarma, Ketut dan Eva M. Sakdiyah. 2007. "Pengaruh Motivasi, Disiplin, dan Partisipasi Siswa Dalam Pembelajaran Terhadap Prestasi Belajar Akuntansi”. Jurnal Pendidikan Ekonomi, Volume 2, Nomor 2 (hlm. 1-20).

Toni, I Wayan Kantun, dkk. 2013. "Determinasi Konsep Diri, Motivasi Berprestasi, dan Disiplin Belajar terhadap Hasil Belajar IPA SD Se-Kecamatan Buleleng". Program Pascasarjana Universitas Pendidikan Ganesha, Volume 3 (hlm. 1-11). 